\title{
STATUS GIZI ANAK BALITA DAN KARAKTERISTIKNYA DI DUA KECAMATAN DI KOTA PEKANBARU
}

\author{
Sri Desfita, Yuyun Priwahyuni \\ Program Studi Ilmu Kesehatan Masyarakat, STIKes Hang Tuah Pekanbaru \\ dear_deshi@yahoo.com
}

\begin{abstract}
ABSTRAK
Berdasarkan profil kesehatan Provinsi Riau tahun 2010 diketahui bahwa prevalensi status gizi pendek di Kota Pekanbaru sebesar 30,2 persen. Batas masalah kesehatan masyarakat untuk status gizi pendek adalah lebih dari 20 persen. ${ }^{5}$ Dengan demikian masalah kekurangan gizi masih menjadi masalah kesehatan masyarakat di Kota Pekanbaru. Penelitian ini bertujuan untuk mengetahui status gizi anak balita dan hubungannya dengan riwayat menyusui dan pengetahuan gizi ibu di kota Pekanbaru. Jenis penelitian adalah observasional dengan desain cross-sectional. Populasi adalah seluruh anak balita di kecamatan Sail dan kecamatan Tampan, kota Pekanbaru. Sampel adalah anak balita berusia 6 - 60 bulan sebanyak 194 anak balita. Teknik sampling menggunakan purposive dalam pemilihan kecamatan, dan secara consecutive sampling dalam pemilihan subjek penelitian. Variabel penelitian adalah status gizi anak balita sebagai variabel terikat dan riwayat menyusui (inisiasi menyusu dini dalam 1 jam setelah lahir, pemberian kolostrum, dan pemberian ASI eksklusif), serta pengetahuan gizi ibu sebagai variabel bebas. Data dianalisis secara univariat dan bivariat menggunakan uji chi-square dan uji fisher exact. Hasil menunjukkan bahwa 25 persen anak balita mengalami status gizi pendek, 9,25 persen mengalami gizi kurang, dan 4,16 persen mengalami kurus. Inisiasi menyusu dini, pemberian kolostrum, dan pemberian ASI eksklusif tidak berhubungan dengan status gizi anak balita $(p>0,05)$. Pengetahuan gizi ibu tidak berhubungan dengan status gizi anak balita $(p>0,05)$. Dapat disimpulkan bahwa masalah gizi pada anak balita di kota Pekanbaru terutama adalah status gizi pendek. Riwayat menyusui dan pengetahuan gizi ibu bukan merupakan faktor risiko yang signifikan terhadap status gizi anak balita di kota Pekanbaru.
\end{abstract}

Kata kunci: status gizi, riwayat menyusui, pengetahuan gizi ibu, balita

\section{ABSTRACT \\ NUTRITIONAL STATUS OF UNDER-FIVE-YEAR-OLD CHILDREN AND ITS CHARACTERICTICS AT TWO SUB-DISTRICTS IN KOTA PEKANBARU}

According to the health profile of Riau Province in 2010, the prevalence of stunting in under five year old children in Kota Pekanbaru is 30,2 per cent. The cut-off point of prevalence value to be a public health significance for stunting higher than 20 per cent. Therefore, stunting remained to be a public health problem in Kota Pekanbaru The study aimed to assess the nutritional status of under-five-year-old children and its association with breastfeeding history and mothers knowledge on nutrition. The study was observational using crossectional design. The study population was all children aged under five years in Sail Sub District and Tampan Sub District, Kota Pekanbaru. The samples were taken consecutively among 6-60 months children. The total samples were 194 children. Purposive sampling was used to select the sub district and consecutive sampling was used to select the subject. Variables studied included nutritional status using anthropometry as dependent variable, breastfeeding history (initiation of breastfeeding within 1 hour of birth, colostrum feeding, and exclusive breastfeeding) and mothers knowledge on nutrition as independent variables. Data analysis was used for univariate and bivariate using chi square and fisher exact tests. The results showed that 25 per cent of children were stunted, 9.25 per cent were underweight while 4.16 per cent were wasted. Initiation of breastfeeding within 1 hour after birth, colostrum feeding and exclusive breastfeeding, as well as mothers knowledge on nutrition were not significantly associated $(p>0.05$ ) with nutritional status of children under-five years. In conclusion, stunted is the major nutritional problem in Kota Pekanbaru. Breastfeeding history and mothers knowledge on nutrition were not significant risk factors for undernutrition among children under-five years.

Keywords: nutritional status, breastfeeding history, mothers knowledge on nutrition, children under-five 


\section{PENDAHULUAN}

$\mathrm{M}$ alnutrisi merupakan penyebab dasar kematian dari 2,6 juta anak-anak setiap tahun serta menyebabkan gangguan fisik dan mental. Lebih dari 170 juta anak-anak di seluruh dunia tidak memiliki kesempatan untuk mencapai potensi pertumbuhan yang optimal karena kekurangan gizi pada awal kehidupan. ${ }^{1}$

Para ahli merekomendasikan bahwa bayi disusui dalam satu jam setelah lahir, pemberian air susu ibu (ASI) eksklusif sampai 6 bulan, dan kemudian disusui sampai usia dua tahun, serta mendapatkan makanan pendamping yang cukup, bergizi dan aman sesuai dengan usia. Pemberian makanan yang optimal dan sesuai dengan ketentuan ini dapat mencegah sekitar 19 persen dari semua kematian pada anak balita. Namun, sebagian besar anak-anak di seluruh dunia tidak disusui secara optimal. ${ }^{1}$

Ketika ASI tidak lagi dapat memenuhi kebutuhan bayi, makanan tambahan perlu diberikan. Transisi dari ASI eksklusif ke makanan keluarga khususnya dari usia 6 bulan sampai dengan 18-24 bulan adalah periode yang peka terhadap kekurangan gizi. Periode ini merupakan periode awal terjadinya malnutrisi dan berkontribusi signifikan pada tingginya prevalensi malnutrisi pada anak balita di seluruh dunia. Diperkirakan 2 dari 5 anak mengalami status gizi pendek (stunted) di negara-negara berkembang. ${ }^{2}$

Berdasarkan hasil Riset Kesehatan Dasar (Riskesdas) tahun 2010, sebesar 35,6 persen anak balita di Indonesia mengalami status gizi pendek. $^{3}$ Profil kesehatan provinsi Riau tahun 2010 menunjukkan prevalensi status gizi pendek pada anak balita adalah 33 persen. Prevalensi status gizi pendek pada anak balita di Kota Pekanbaru sebagai ibu kota provinsi Riau sebesar 30,2 persen. ${ }^{4}$ Batas masalah kesehatan masyarakat untuk status gizi pendek adalah $>20$ persen. ${ }^{5}$ Dengan demikian masalah kekurangan gizi masih menjadi masalah kesehatan masyarakat di Kota Pekanbaru.

Beberapa penelitian menunjukkan adanya hubungan antara riwayat menyusui dan pengetahuan gizi ibu dengan status gizi anak balita. Penelitian di Kenya menemukan bahwa terdapat hubungan keterlambatan inisiasi menyusu dini (IMD) dengan terjadinya status gizi pendek pada anak usia 0-24 bulan. Anak yang IMD setelah satu jam berpeluang dua kali untuk mengalami status gizi pendek dibanding anak yang mendapatkan IMD dalam satu jam setelah lahir. ${ }^{6}$ Penelitian di Turki menemukan proporsi status gizi pendek pada anak balita yang diberi kolostrum 11,2 persen signifikan lebih rendah dibanding proporsi status gizi pendek pada anak yang tidak diberi kolostrum sebesar 31,7 persen. Anak yang tidak mendapatkan kolostrum berisiko 2,7 kali untuk mengalami status gizi pendek. ${ }^{7}$ Penelitian di Nusa Tenggara Timur (NTT) yang meneliti faktor-faktor yang mempengaruhi status gizi anak balita menunjukkan bahwa riwayat pemberian ASI dan pengetahuan gizi ibu berhubungan dengan status gizi anak balita. ${ }^{8}$

Kota Pekanbaru dikenal sebagai kota bisnis dan mengalami kemajuan dengan pesat di sektor perekonomian. Namun masih terdapat anak-anak balita kekurangan gizi yang tidak dapat merasakan dampak dari kemajuan kotanya. Anak balita yang mengalami kekurangan gizi akan mempengaruhi perkembangan mental dan psikomotor, anak mudah lelah dan rentan terhadap penyakit. Bahkan efek jangka panjang dari kekurangan gizi ini menyebabkan menurunnya kapasitas intelektual dan produktivitas anak setelah dewasa nanti. Hal ini dapat disebabkan karena anak tidak mendapatkan IMD dan kolostrum pada waktu baru lahir, serta tidak mendapatkan ASI eksklusif sampai 6 bulan. Pengetahuan gizi ibu yang kurang juga dapat menyebabkan anak mengalami gizi kurang. Penelitian ini bertujuan untuk mengetahui hubungan riwayat menyusui dan pengetahuan gizi ibu dengan status gizi anak balita di Kota Pekanbaru.

\section{METODE PENELITIAN}

Penelitian ini merupakan penelitian observasional dengan desain cross-sectional. Populasi penelitian adalah seluruh anak balita di kecamatan Sail dan kecamatan Tampan, kota Pekanbaru, selama bulan Agustus 2013 sampai dengan Oktober 2013. Sampel adalah anak balita berusia 6-60 bulan dengan kriteria inklusi anak balita dalam keadaan sehat, bila terdapat lebih dari satu anak balita dalam satu keluarga maka yang diambil adalah anak balita dengan usia termuda. Kriteria eksklusi adalah anak 
balita yang tinggal terpisah dengan ibu kandungnya. Responden penelitian adalah ibu dari anak balita yang bersedia mengikuti penelitian dengan menandatangani informed consent.

Diketahui proporsi anak balita yang tidak mendapatkan ASI eksklusif dan mengalami gizi kurang adalah 39,2 persen, ${ }^{9}$ dengan kesalahan tipe I sebesar 5 persen, hipotesis 2 arah, kesalahan tipe II sebesar 20 persen, dan selisih proporsi minimal yang dianggap bermakna sebesar 20 persen, berdasarkan rumus uji hipotesis untuk dua proporsi populasi ${ }^{10}$ maka besar sampel untuk masing-masing kelompok terpajan dan kelompok tidak terpajan adalah 97 atau total sampel adalah 194. Teknik sampling dilakukan secara purposive yaitu dengan memilih kecamatan berdasarkan pertimbangan kecamatan yang memiliki prevalensi status gizi pendek tertinggi pada anak balita serta kecamatan yang terletak di pusat kota dan kecamatan yang terletak di pinggir kota, sedangkan pemilihan subjek penelitian dilakukan secara consecutive sampling berdasarkan kriteria inklusi dan eksklusi.

Variabel terikat dalam penelitian ini adalah status gizi (indikator BB/U, TB/U, dan BB/TB) sedangkan variabel bebas terdiri dari riwayat menyusui (IMD, pemberian kolostrum, dan pemberian ASI eksklusif) dan pengetahuan gizi ibu. Data status gizi diperoleh melalui penimbangan berat badan dengan menggunakan dacin serta pengukuran panjang badan menggunakan alat pengukur panjang badan sedangkan pengukuran tinggi badan menggunakan microtoise. Kategori status gizi menggunakan z-skor berdasarkan standar antropometri WHO 2005. Anak balita dengan zskor < -2 standar deviasi (SD) untuk indikator $\mathrm{BB} / \mathrm{U}, \mathrm{TB} / \mathrm{U}$, dan BB/TB diklasifikasikan masingmasing sebagai gizi kurang, pendek, dan kurus, sedangkan bila <-3 SD untuk indikator yang sama masing-masing diklasifikasikan sebagai gizi buruk, sangat pendek, dan sangat kurus. Klasifikasi status gizi baik atau normal bila zskor -2 SD sampai dengan 2 SD. Status gizi lebih, tinggi, atau gemuk adalah bila z-skor $>2$ SD. Data status gizi diolah dengan program WHO Anthro 2005 serta data yang diperoleh dari kuesioner diolah dengan menggunakan program komputer.

Data riwayat menyusui terdiri dari IMD dalam satu jam setelah lahir, pemberian kolostrum, dan pemberian ASI eksklusif sampai usia 6 bulan ditanyakan ke seluruh responden. Pengetahuan gizi ibu diperoleh melalui kuesioner dengan kategori kurang $<60 \%$ jawaban benar) dan baik $(\geq 60 \%$ jawaban benar).

Analisis data secara univariat dan bivariat dengan menggunakan uji chi-square dan uji fisher exact.

\section{HASIL}

Penelitian dilaksanakan di kecamatan Sail dan kecamatan Tampan, Kota Pekanbaru. Jumlah subjek keseluruhan dari dua kecamatan adalah 216 yang terdiri dari 100 subjek di kecamatan Sail dan 116 subjek di kecamatan Tampan. Jumlah subjek penelitian telah memenuhi besar sampel minimal untuk penelitian ini yaitu 194 subjek.

Tabel 1 menunjukkan karakteristik sosiodemografi subjek. Usia subjek paling banyak pada usia 6 sampai 12 bulan yaitu 38,4 persen. Jenis kelamin balita diketahui 51,4 persen laki-laki. Sebagian besar subjek memiliki berat badan lahir normal yaitu 94,9 persen. Tingkat pendidikan ibu subjek sebesar 75 persen termasuk pendidikan tinggi, penghasilan keluarga sama dengan UMK atau lebih sebesar 69 persen, dan sebagian besar ibu balita tidak bekerja $(89,8 \%)$.

Tabel 2 menunjukkan terdapat 3 subjek $(1,4 \%)$ memiliki status gizi buruk, 13 subjek (6\%) memiliki status gizi sangat pendek, dan 1 subjek $(0,5 \%)$ memiliki status gizi sangat kurus. Status gizi antar kecamatan tidak jauh berbeda namun secara umum status gizi subjek di kecamatan Tampan sedikit lebih baik dibandingkan status gizi subjek di kecamatan Sail.

Tabel 3 menunjukkan status gizi subjek menurut karakteristik sosiodemografi. Balita yang mengalami status gizi kurang (gizi kurang dan gizi buruk) 9,25 persen, pendek (pendek dan sangat pendek) 25 persen dan kurus (kurus dan sangat kurus) 4,16 persen. Prevalensi kekurangan gizi bervariasi menurut usia subjek. Prevalensi terbesar status gizi kurang dan status gizi kurus terjadi pada kelompok usia 49 sampai 60 bulan yaitu masing-masing 28,57 persen dan 14,2 persen. Prevalensi terbesar status gizi pendek terjadi pada usia 13 sampai 24 bulan yaitu 30,9 persen. Terjadi peningkatan 
prevalensi status gizi kurang dan kurus pada usia 49 sampai 60 bulan, sedangkan prevalensi status gizi pendek sedikit menurun pada usia 49 sampai 60 bulan yaitu menjadi 28,57 persen.

Jenis kelamin subjek terdiri dari laki-laki (111) dan perempuan (105). Status gizi kurang lebih banyak terjadi pada perempuan daripada laki-laki, sedangkan status gizi pendek dan kurus lebih banyak terjadi pada laki-laki daripada perempuan.

Berat badan lahir subjek sebagian besar $(94,4 \%) \geq 2500$ gram. Status gizi kurang, pendek, dan kurus lebih banyak terjadi pada subjek yang memiliki berat badan lahir $\geq 2500$ gram.

Status gizi kurang dan kurus lebih banyak terjadi pada kelompok ibu berpendidikan rendah. Sedangkan status gizi pendek lebih banyak terjadi pada kelompok ibu berpendidikan tinggi. Status gizi kurang dan kurus lebih banyak terjadi pada subjek dengan penghasilan keluarga di bawah Upah Minimum Kota (UMK), sedangkan status gizi pendek lebih banyak terjadi pada kelompok subjek dengan penghasilan keluarga sama dengan UMK atau lebih.

Status gizi kurang, pendek, dan kurus lebih banyak terjadi pada subjek yang memiliki ibu bekerja. Hubungan status gizi dengan karakteristik sosiodemografi berdasarkan uji chisquare dan uji Fisher Exact tidak bermakna ( $p>$ 0,05).

Riwayat menyusui dan pengetahuan gizi ibu dianalisis untuk mengetahui risiko terhadap status gizi menggunakan odds rasio (OR) dengan interval kepercayaan (IK) 95\% (Tabel 4). IMD, pemberian kolostrum, pemberian ASI eksklusif, dan pengetahuan gizi ibu bukan merupakan faktor risiko yang signifikan terhadap status gizi kurang, pendek, dan kurus $(p>0,05)$.

Tabel 1

Distribusi Subjek Berdasarkan Karakteristik Sosiodemografi

\begin{tabular}{|c|c|c|}
\hline Karakteristik & $\mathrm{n}$ & $\%$ \\
\hline \multicolumn{3}{|l|}{ Usia (bulan) } \\
\hline $6-12$ & 83 & 38,4 \\
\hline $13-24$ & 55 & 25,5 \\
\hline $25-36$ & 43 & 19,9 \\
\hline $37-48$ & 21 & 9,7 \\
\hline $49-60$ & 14 & 6,5 \\
\hline \multicolumn{3}{|l|}{ Jenis Kelamin } \\
\hline Laki-laki & 111 & 51,4 \\
\hline Perempuan & 105 & 48,6 \\
\hline \multicolumn{3}{|l|}{ Berat Badan Lahir (*) } \\
\hline$<2500$ gram & 11 & 5,1 \\
\hline$\geq 2500$ gram & 204 & 94,9 \\
\hline \multicolumn{3}{|l|}{ Tingkat Pendidikan Ibu } \\
\hline Rendah (SD, SMP) & 54 & 25,0 \\
\hline Tinggi ( $\geq$ SMA) & 162 & 75,0 \\
\hline \multicolumn{3}{|l|}{ Penghasilan Keluarga } \\
\hline < UMK (Rp. 1.450.000) & 67 & 31,0 \\
\hline z UMK (Rp. 1.450.000) & 149 & 69,0 \\
\hline \multicolumn{3}{|l|}{ Pekerjaan Ibu } \\
\hline Bekerja & 22 & 10,2 \\
\hline Tidak Bekerja & 194 & 89,8 \\
\hline Total & 216 & 100 \\
\hline
\end{tabular}


Tabel 2

Distribusi Status Gizi Subjek Berdasarkan Kecamatan

\begin{tabular}{cccccccc}
\hline \multirow{2}{*}{ Status gizi } & \multicolumn{3}{c}{ Kecamatan Sail } & \multicolumn{3}{c}{ Kecamatan Tampan } & \multicolumn{3}{c}{ Total } \\
\cline { 2 - 8 } & $\mathrm{n}$ & $\%$ & $\mathrm{n}$ & $\%$ & $\mathrm{n}$ & $\%$ \\
\hline BB/U & & & & & & & \\
- & Buruk & 2 & 2,0 & 1 & 0,9 & 3 & 1,4 \\
- & Kurang & 9 & 9,0 & 8 & 6,9 & 17 & 7,9 \\
- & Baik & 89 & 89,0 & 104 & 89,7 & 193 & 89,4 \\
- & Lebih & - & & 3 & 2,6 & 3 & 1,4 \\
\hline TB/U & & & & & & & \\
- & Sangat pendek & 8 & 8,0 & 5 & 4,3 & 13 & 6 \\
- & Pendek & 21 & 21,0 & 20 & 17,2 & 41 & 19 \\
- & Normal & 70 & 70,0 & 88 & 75,9 & 158 & 73,1 \\
- & Tinggi & 1 & 1,0 & 3 & 2,6 & 4 & 1,9 \\
\hline BB/TB & & & & & & & \\
- & Sangat kurus & 1 & 1,0 & - & - & 1 & 0,5 \\
- & Kurus & 4 & 4,0 & 4 & 3,4 & 8 & 3,7 \\
- & Normal & 91 & 91,0 & 107 & 92,2 & 198 & 91,7 \\
- & Gemuk & 4 & 4,0 & 5 & 4,3 & 9 & 4,2 \\
\hline
\end{tabular}

Tabel 3

Status Gizi Subjek dan Hubungannya dengan Karakteristik Sosiodemografi

\begin{tabular}{|c|c|c|c|c|c|c|}
\hline \multirow{2}{*}{ Karakteristik } & \multicolumn{2}{|c|}{ Gizi Kurang } & \multicolumn{2}{|c|}{ Pendek } & \multicolumn{2}{|c|}{ Kurus } \\
\hline & $\mathrm{n}$ & $\%$ & $\mathrm{n}$ & $\%$ & $\mathrm{n}$ & $\%$ \\
\hline \multicolumn{7}{|l|}{ Usia (bulan) } \\
\hline $6-12$ & 7 & 8,43 & 16 & 19,20 & - & - \\
\hline $13-24$ & 2 & 3,63 & 17 & 30,90 & 3 & 5,45 \\
\hline $25-36$ & 4 & 9,30 & 13 & 30,20 & 2 & 4,65 \\
\hline $37-48$ & 3 & 14,28 & 4 & 19,04 & 2 & 9,50 \\
\hline $49-60$ & 4 & 28,57 & 4 & 28,57 & 2 & 14,20 \\
\hline \multicolumn{7}{|l|}{ Jenis kelamin } \\
\hline Laki-laki & 8 & 7,20 & 31 & 27,90 & 6 & 5,40 \\
\hline Perempuan & 12 & 11,40 & 23 & 21,90 & 3 & 2,90 \\
\hline$p$ value & & $0,40^{a}$ & & $0,30^{a}$ & & $0,50^{b}$ \\
\hline \multicolumn{7}{|l|}{ Berat badan lahir } \\
\hline$<2500 \mathrm{~g}$ & 0 & 0 & 3 & 27,30 & 0 & 0 \\
\hline$\geq 2500 \mathrm{~g}$ & 19 & 9,30 & 51 & 25,00 & 9 & 4,40 \\
\hline$p$ value & & $0,60^{b}$ & & $1,00^{b}$ & & $1,00^{b}$ \\
\hline \multicolumn{7}{|l|}{ Tingkat penddikan ibu } \\
\hline Rendah (SD, SMP) & 6 & 11,10 & 8 & 14,80 & 3 & 5,60 \\
\hline Tinggi ( $\geq$ SMA) & 14 & 8,60 & 46 & 28,40 & 6 & 3,70 \\
\hline$p$ value & & $0,70^{a}$ & & $0,07 a$ & & $0,60^{b}$ \\
\hline \multicolumn{7}{|l|}{ Penghasilan keluarga } \\
\hline$<$ UMK $(\operatorname{Rp} 1.450 .000,00$ & 8 & 11,9 & 16 & 23,90 & 4 & 6,00 \\
\hline$\geq$ UMK $(\operatorname{Rp} 1.450 .000,00)$ & 12 & 8,1 & 38 & 25,50 & 5 & 3,40 \\
\hline p value & & $0,5^{\mathrm{a}}$ & & $0,90 \mathrm{a}$ & & $0,40^{b}$ \\
\hline \multicolumn{7}{|l|}{ Pekerjaan ibu } \\
\hline Bekerja & 3 & 13,60 & 7 & 31,80 & 1 & 4,50 \\
\hline Tidak bekerja & 17 & 8,80 & 47 & 24,20 & 8 & 4,10 \\
\hline$p$ value & & $0,40^{\mathrm{b}}$ & & $0,60^{a}$ & & $1,00^{\mathrm{b}}$ \\
\hline Total & 20 & 9,25 & 54 & 25,0 & 9 & 4,16 \\
\hline
\end{tabular}


Tabel 4

Hubungan Riwayat Menyusui dan Pengetahuan Gizi Ibu dengan Status Gizi

\begin{tabular}{|c|c|c|c|c|c|c|c|c|c|}
\hline \multirow{3}{*}{$\begin{array}{l}\text { Riwayat Menyusui } \\
\text { dan Pengetahuan } \\
\text { Gizi lbu }\end{array}$} & \multicolumn{9}{|c|}{ Status Gizi } \\
\hline & \multicolumn{3}{|c|}{ Gizi Kurang } & \multicolumn{3}{|c|}{ Pendek } & \multicolumn{3}{|c|}{ Kurus } \\
\hline & $\mathrm{n}$ & $\%$ & OR (IK) & $\mathrm{n}$ & $\%$ & OR (IK) & $\mathrm{n}$ & $\%$ & OR (IK) \\
\hline \multicolumn{10}{|l|}{ IMD : } \\
\hline Setelah 1 jam & 4 & 9,5 & $1,0(0,3-3,2)$ & 9 & 21,4 & $0,7(0,3-1,7)$ & 1 & 2,4 & $0,5(0,0-4,1)$ \\
\hline Dalam 1 jam & 16 & 9,2 & & 45 & 25,9 & & 8 & 4,6 & \\
\hline$p$ value & & & $1,0 \mathrm{a}$ & & & $0,6^{b}$ & & & $1,0 \mathrm{a}$ \\
\hline \multicolumn{10}{|l|}{$\begin{array}{l}\text { Pemberian } \\
\text { kolostrum : }\end{array}$} \\
\hline Tidak & 5 & 10,4 & $1,18(0,4-3,4)$ & 9 & 18,8 & $0,6(0,2-1,4)$ & 2 & 4,2 & $1,0(0,2-4,9)$ \\
\hline $\mathrm{Ya}$ & 15 & 8,9 & & 45 & 26,8 & & 7 & 4,2 & \\
\hline$p$ value & & & $0,7^{a}$ & & & $0,3^{b}$ & & & $1,0^{a}$ \\
\hline \multicolumn{10}{|l|}{$\begin{array}{l}\text { Pemberian ASI } \\
\text { eksklusif : }\end{array}$} \\
\hline Tidak & 7 & 9,9 & $1,11(0,4-2,9)$ & 18 & 25,4 & $1,0(0,5-1,9)$ & 5 & 7,0 & $2,6(0,6-10,2)$ \\
\hline Ya & 13 & 9,0 & & 36 & 24,8 & & 4 & 2,8 & \\
\hline$p$ value & & & $1,0^{b}$ & & & $1,0^{b}$ & & & $0,1^{a}$ \\
\hline \multicolumn{10}{|l|}{$\begin{array}{l}\text { Pengetahuan Gizi } \\
\text { lbu: }\end{array}$} \\
\hline Kurang & 0 & 0,0 & - & 3 & 21,4 & $0,8(0,2-3,0)$ & 0 & 0,0 & - \\
\hline Baik & 20 & 9,9 & & 51 & 25,2 & & 9 & 4,5 & \\
\hline$p$ value & & & $0,3^{a}$ & & & $1,0^{a}$ & & & $1,0^{a}$ \\
\hline Total & 20 & 9,25 & & 54 & 25 & & 9 & 4,16 & \\
\hline
\end{tabular}

Subjek dengan IMD setelah satu jam lebih cenderung untuk mengalami status gizi kurang (9,5\%), dibandingkan subjek dengan IMD dalam satu jam dan mengalami status gizi kurang $(9,2 \%)$. Subjek yang tidak mendapatkan kolostrum cenderung untuk mengalami status gizi kurang $(10,4 \%)$ dibandingkan dengan subjek yang mendapatkan kolostrum dan mengalami status gizi kurang (8,9\%).

Proporsi status gizi kurang, pendek, dan kurus pada subjek yang tidak mendapatkan ASI eksklusif lebih besar (masing-masing 9,9\%, $25,4 \%$ dan $7,0 \%$ ) dibandingkan subjek yang mendapatkan ASI eksklusif (masing-masing $9,0 \%, 24,8 \%$, dan 2,8\%). Dapat dikatakan bahwa status gizi kurang, pendek, dan kurus cenderung terjadi pada subjek yang tidak mendapatkan ASI eksklusif dibandingkan subjek yang mendapatkan ASI eksklusif. Namun hasil penelitian ini tidak bermakna dengan nilai $p>0,05$.

Sebagian besar $(93,5 \%)$ pengetahuan gizi ibu baik. Proporsi status gizi kurang, pendek, dan kurus lebih banyak terjadi pada subjek yang memiliki ibu dengan pengetahuan gizi baik.
Hasil uji Fisher Exact menunjukkan tidak terdapat hubungan yang bermakna antara pengetahuan gizi ibu dengan status gizi $(p>0,05)$.

\section{BAHASAN}

\section{Status Gizi Subjek}

Masalah kekurangan gizi masih terjadi di Kota Pekanbaru, khususnya di Kecamatan Sail dan Kecamatan Tampan. Terdapat 25 persen anak balita mengalami status gizi pendek. Prevalensi status gizi pendek ini lebih besar dibanding dengan prevalensi status gizi pendek hasil Pemantauan Status Gizi (PSG) yang dilaksanakan oleh Dinas Kesehatan Kota Pekanbaru melalui puskesmas tahun 2013 yaitu hanya 11,16 persen. ${ }^{11}$ Perbedaan ini dapat terjadi disebabkan karena perbedaan dalam cara pengukuran panjang badan atau tinggi badan. Penelitian ini menggunakan alat pengukur panjang badan (length board) untuk mengukur panjang badan anak $\leq 2$ tahun serta menggunakan microtoise untuk mengukur tinggi badan anak > 2 tahun, sehingga hasil 
pengukuran lebih valid dan reliabel. Batas ambang masalah kesehatan masyarakat untuk status gizi pendek adalah $>20$ persen, ${ }^{5}$ dengan demikian status gizi pendek masih merupakan masalah gizi utama pada anak balita di Kota Pekanbaru.

Secara global dari 165 juta anak balita, 26 persen mengalami status gizi pendek. ${ }^{12}$ Pendek merupakan akibat jangka panjang dari kekurangan gizi dan dapat mengakibatkan keterlambatan perkembangan mental dan menurunkan kapasitas intelektual. Perempuan dewasa yang pendek memiliki risiko yang lebih besar terhadap komplikasi kehamilan karena panggul yang sempit, dan juga berisiko untuk melahirkan bayi berat lahir rendah. Hal ini menyebabkan siklus malnutrisi antar generasi karena bayi yang lahir dengan berat lahir rendah atau pertumbuhan dalam rahim yang terhambat cenderung untuk menjadi orang dewasa yang pendek. ${ }^{13}$ Orang dewasa yang pendek berhubungan dengan rendahnya produktivitas serta lebih berisiko untuk menderita penyakit-penyakit seperti hipertensi, diabetes, jantung, dan obesitas..$^{14,15}$

Status gizi pendek biasanya terjadi sebelum usia 2 tahun dan efeknya tidak dapat diperbaiki seperti keterlambatan perkembangan motorik dan gangguan fungsi kognitif. ${ }^{1}$ Hasil penelitian ini menunjukkan hal yang sama yaitu prevalensi status gizi pendek yang tertinggi terjadi pada usia 13 sampai 24 bulan yaitu 30,9 persen. Anak di bawah usia 2 tahun berada pada periode kritis pertumbuhan yang disebut juga dengan window of opportunity atau periode emas pertumbuhan. Kekurangan gizi pada usia ini bersifat menetap yang menyebabkan pertumbuhan dan perkembangan anak tidak optimal.

Gizi yang baik pada seribu hari pertama kehidupan yang dimulai dari awal kehamilan sampai usia 2 tahun adalah periode kritis untuk kesehatan di masa depan, dan keberhasilan seorang anak. Gizi yang tepat selama usia ini mempunyai pengaruh yang sangat besar terhadap kemampuan anak untuk tumbuh, belajar, dan keluar dari kemiskinan. Hal ini juga bermanfaat bagi masyarakat dengan mendorong produktivitas dan meningkatkan masa depan perekonomian bagi keluarga dan masyarakat. ${ }^{1}$

Prevalensi gizi kurang pada penelitian ini sebesar 9,25 persen dan prevalensi kurus 4,16 persen. Hasil penelitian ini sedikit lebih rendah dibanding dengan hasil PSG oleh Dinas Kesehatan Kota Pekanbaru tahun 2013 yang mendapatkan prevalensi gizi kurang dan kurus masing-masing sebesar 10,22 persen dan 4,94 persen. ${ }^{11}$ Masalah gizi kurang dan kurus masih di bawah ambang batas masalah gizi sebagai masalah kesehatan masyarakat yaitu ambang batas untuk gizi kurang $>10$ persen dan kurus $>$ 5 persen. ${ }^{5}$

Namun status gizi buruk, sangat pendek, dan sangat kurus masih terdapat di dua kecamatan. Terdapat 3 subjek $(1,4 \%)$ memiliki status gizi buruk, 13 subjek (6\%) memiliki status gizi sangat pendek, serta 1 subjek $(0,5 \%)$ memiliki status gizi sangat kurus. Ketiga bentuk kekurangan gizi ini bersifat kritis dan harus segera mendapatkan intervensi untuk memperbaiki status gizinya.

Berdasarkan usia subjek yang mengalami gizi kurang dan status gizi kurus, prevalensi tertinggi terjadi pada kelompok usia 49 sampai 60 bulan yaitu masing-masing 28,57 persen dan 14,2 persen.

Program promosi kesehatan wajib dilaksanakan oleh puskesmas untuk meningkatkan derajat kesehatan masyarakat di wilayah kerjanya. Program promosi kesehatan dilaksanakan dengan biaya yang lebih murah dari kuratif dan rehabilitatif, juga karena $85-90 \%$ penduduk Indonesia yang sehat, perlu tetap dijaga kesehatannya agar tidak jatuh sakit. ${ }^{16}$ Berdasarkan observasi dan wawancara dengan petugas gizi puskesmas diketahui bahwa petugas program promosi kesehatan di wilayah kerja Puskesmas Sail dan Puskesmas Sidomulyo sangat terbatas. Selama pelaksanaan penelitian lebih kurang 3 bulan tidak pernah dilaksanakan penyuluhan di posyandu.

\section{Hubungan Riwayat Menyusui dengan Status Gizi}

Praktik pemberian makan pada bayi menentukan status gizi anak. Sekitar 60 persen semua kematian pada anak kurang dari 5 tahun secara langsung dan tidak langsung disebabkan karena malnutrisi. Sekitar 2/3 dari kematian tersebut berhubungan dengan praktik pemberian makan yang tidak baik dan terjadi selama tahun pertama usia anak. WHO merekomendasikan bahwa bayi mulai diberi ASI dalam satu jam pertama kelahirannya, 
pemberian ASI eksklusif sampai 6 bulan, dan memperkenalkan makanan tambahan yang cukup, aman, dan baik sesuai dengan usia serta melanjutkan pemberian ASI eksklusif sampai usia 2 tahun atau lebih. ${ }^{17}$

Hasil penelitian ini tidak menunjukkan hubungan yang bermakna antara IMD dalam satu jam setelah lahir, pemberian kolostrum, dan pemberian ASI eksklusif dengan status gizi anak balita baik untuk status gizi kurang, pendek, maupun kurus. Hal ini dapat disebabkan karena besar sampel yang tidak terpenuhi untuk kelompok IMD setelah 1 jam, kelompok yang tidak memberikan kolostrum, dan kelompok yang tidak memberikan ASI eksklusif yang masing-masing hanya mendapatkan 42, 48, dan 71 subjek.

Penelitian ini menunjukkan sebagian besar ibu melaksanakan IMD dalam 1 jam yaitu sebesar $80,6 \%$. Ibu yang tidak melaksanakan IMD pada penelitian ini disebabkan karena ASI tidak keluar, bayi sudah diberi susu formula pada waktu lahir, dan ibu yang melahirkan dengan operasi.

Hasil penelitian ini sejalan dengan penelitian di India yang tidak menemukan hubungan IMD dalam 1 jam setelah lahir dengan status gizi, baik untuk gizi kurang, pendek maupun kurus pada anak usia kurang dari 12 bulan..$^{18}$ Namun berbeda dengan penelitian di Kenya yang menemukan bahwa terdapat hubungan keterlambatan inisiasi menyusu dini dengan terjadinya status gizi pendek pada anak usia 0-24 bulan. Anak yang IMD setelah 1 jam berpeluang 2 kali untuk mengalami status gizi pendek dibanding anak yang mendapatkan IMD dalam satu jam setelah lahir. ${ }^{6}$ Penelitian lain di India juga menunjukkan bahwa keterlambatan pemberian inisiasi ASI berhubungan signifikan dengan terjadinya gizi kurang dan pendek pada anak balita, namun tidak berhubungan dengan status gizi kurus. ${ }^{9}$ Penelitian kasus kontrol di Puskesmas Kecamatan Pancoran Mas Depok menemukan IMD merupakan faktor risiko terhadap status gizi kurang pada bayi usia 6 bulan dengan OR: $5,189(1,797-14,988) \cdot{ }^{19}$

Hasil penelitian ini menunjukkan bayi yang mendapatkan kolostrum sebesar $77,8 \%$. Ibu tidak memberikan kolostrum sebagian besar disebabkan karena ASI tidak keluar setelah melahirkan. Hasil uji Chi Square dan Fisher Exact menunjukkan tidak terdapat hubungan yang bermakna antara pemberian kolostrum dengan status gizi anak balita. Penelitian sebelumnya di India juga menemukan hubungan yang tidak bermakna antara pemberian kolostrum dengan status gizi anak usia $<12$ bulan baik untuk gizi kurang, pendek, maupun kurus. ${ }^{18}$

Hasil penelitian ini berbeda dengan hasil penelitian di Turki yang menemukan proporsi status gizi pendek pada anak balita yang diberi kolostrum 11,2 persen signifikan lebih rendah dibanding proporsi status gizi pendek pada anak yang tidak diberi kolostrum sebesar 31,7 persen. Anak yang tidak mendapatkan kolostrum berisiko 2,7 kali untuk mengalami status gizi pendek. ${ }^{7}$ Penelitian di Etiopia menemukan hubungan yang sangat bermakna antara pemberian kolostrum dengan status gizi pendek pada anak balita. Sebesar 52,0 persen anak yang tidak mendapatkan kolostrum mengalami pendek dibandingkan dengan anak yang mendapatkan kolostrum yang mengalami pendek hanya 32,2 persen. ${ }^{20}$

Pemberian ASI eksklusif pada penelitian ini sebesar 67,1 persen. Beberapa alasan yang dikemukakan ibu mengenai pemberian makanan tambahan sebelum usia 6 bulan antara lain karena ASI kurang, agar bayi kenyang, bayi rewel, dianjurkan oleh orang tua ibu, dan bayi tidak mau menyusu. Banyak faktor yang menyebabkan ibu tidak memberikan ASI eksklusif sampai 6 bulan. Penelitian ini menunjukkan bahwa pengetahuan ibu yang kurang, peran orang tua, serta peran petugas kesehatan dalam mendorong ibu untuk memberikan ASI eksklusif dapat menjadi penyebab tidak berhasilnya ibu dalam memberikan ASI eksklusif. Hasil analisis chi square dan fisher exact menunjukkan tidak terdapat hubungan antara pemberian ASI eksklusif dengan status gizi anak balita.

Beberapa penelitian sejalan dengan hasil penelitian ini. Penelitian di India tidak menemukan hubungan antara pemberian ASI eksklusif dengan status gizi anak usia $<12$ bulan, baik untuk status gizi kurang, pendek, maupun kurus. ${ }^{18}$ Penelitian kohor retrospektif pada anak usia 4-7 tahun di Brazil menunjukkan tidak ada hubungan yang bermakna antara pemberian ASI eksklusif dengan status gizi dengan menggunakan indikator Indeks Massa Tubuh (IMT) menurut umur (IMT/U), total massa lemak tubuh, dan lingkar pinggang. ${ }^{21}$ Demikian 
pula dengan penelitian di Jawa Barat juga menunjukkan hal yang sama bahwa tidak terdapat hubungan yang bermakna antara praktik pemberian ASI eksklusif dengan status gizi pendek pada bayi usia 4-12 bulan. ${ }^{22}$

Hasil penelitian ini berbeda dengan beberapa penelitian seperti penelitian di India yang menemukan terdapat hubungan yang bermakna antara pemberian ASI eksklusif dengan gizi kurang pada anak usia 0-5 tahun. ${ }^{23}$ Penelitian kasus kontrol pada anak usia 6-59 bulan di Nepal juga mendapatkan bahwa pemberian ASI eksklusif yang kurang dari 6 bulan, 6,9 kali lebih tinggi pada kasus yaitu anak pendek dari pada kontrol yaitu anak normal (OR = 6,90, 95\% IK 2,81-16,97). ${ }^{24}$

Penelitian di Kenya menyatakan bahwa tingginya prevalensi malnutrisi pada anak-anak yang menyusui kurang dari 12 bulan dapat dihubungkan dengan fakta bahwa ketika ASI tidak lagi diberikan, porsi makanan pendamping ASI yang diberikan terlalu kecil untuk anak. Anak-anak juga dapat terpapar dengan infeksi yang merupakan akibat dari menurunnya asupan gizi yang akhirnya menimbulkan malnutrisi. Pemberian ASI eksklusif selama 6 bulan dan dilanjutkan dengan pemberian ASI selama 2 tahun dapat menurunkan risiko pendek dan kurus pada anak balita. ${ }^{25}$

\section{Hubungan Pengetahuan Gizi Ibu dengan Status Gizi}

Perilaku makan anak dipengaruhi oleh pengetahuan gizi orang tua. Orang tua secara sadar maupun tidak sadar telah menuntun kesukaan makan anak dan membentuk gaya yang berpengaruh terhadap di mana, bagaimana, dengan siapa, dan berapa banyak ia makan. Tingkat pengetahuan gizi yang dipraktikkan pada perencanaan makanan keluarga tampaknya berhubungan dengan sikap positif ibu terhadap diri sendiri, kemampuan ibu dalam memecahkan masalah, dan mengorganisasi keluarga. ${ }^{26}$

Ibu yang memiliki pengetahuan gizi kurang sebesar 21,4 persen memiliki anak dengan status gizi pendek, sedangkan ibu yang memiliki pengetahuan gizi baik sebesar 25,2 persen memiliki anak dengan status gizi pendek. Berdasarkan uji Fisher Exact perbedaan ini tidak signifikan dengan nilai $p>0,05$. Nilai $O R$ 0,80 dengan IK (95\%) $0,21-3,00$. Sebagian besar ibu $(93,5 \%)$ memiliki pengetahuan gizi yang baik, hanya 6,5 persen ibu yang memiliki pengetahuan gizi kurang. Hal ini dapat menjadi penyebab tidak bermaknanya hasil penelitian.

Hasil penelitian ini berbeda dengan penelitian di Ghana yang menemukan terdapat hubungan signifikan antara pengetahuan ibu tentang kolostrum, usia pemberian makanan tambahan, dan pengetahuan ibu tentang kwashiorkor dengan status gizi anak. ${ }^{27}$ Penelitian di Nusa Tenggara Timur juga menemukan terdapat hubungan yang bermakna antara pengetahuan gizi ibu dengan status gizi anak balita. ${ }^{8}$

Fungsi ibu menjadi sangat penting terutama sampai bayi berusia 1 tahun. Pemberian ASI eksklusif yang kurang dari 6 bulan dan dilanjutkan dengan pemberian Makanan Pendamping ASI (MP-ASI) yang salah dapat memberikan pengaruh yang signifikan pada pertumbuhan dan perkembangan anak. Bila pemberian ASI dan MP-ASI tidak benar akan meningkatkan risiko kekurangan gizi, penyakit, bahkan kematian bayi atau terjadinya penyimpangan pertambahan berat badan yang cenderung menurun. Penyimpangan pertumbuhan atau growth faltering pada usia 46 bulan dapat berlanjut pada kelambatan pertumbuhan badan pada usia balita. ${ }^{28}$

\section{SIMPULAN DAN SARAN}

\section{Simpulan}

Status gizi pendek merupakan masalah gizi utama pada anak balita di Kota Pekanbaru. Masalah kekurangan gizi terutama terjadi pada usia di bawah dua tahun. Penelitian ini tidak dapat membuktikan hubungan antara riwayat menyusui (IMD, pemberian kolostrum, dan pemberian ASI eksklusif) dengan status gizi anak balita. Di samping itu juga tidak menemukan hubungan antara pengetahuan gizi ibu dengan status gizi anak balita.

\section{Saran}

Bagi pihak puskesmas, perlu menambah dan menempatkan tenaga promosi kesehatan yang sesuai dengan bidang ilmu di setiap puskesmas di Kota Pekanbaru, perlu dilaksanakan pengukuran panjang dan tinggi badan di posyandu dengan alat ukur yang valid seperti pengukur panjang badan dan microtoise. Selain itu perlu segera menanggulangi masalah gizi 
buruk, sangat pendek, dan sangat kurus, dan juga memprioritaskan anak di bawah dua tahun sebagai periode emas pertumbuhan dalam program gizi.

\section{RUJUKAN}

1. Save the Children. Nutrition in the first 1,000 days. State of the world's mothers. London: Unicef, 2012.

2. World Health Organization. Complementary feeding. Geneva: WHO, 2013.

3. Kementerian Kesehatan RI. Riset Kesehatan Dasar (Riskesdas). Laporan Nasional. Jakarta: Badan Penelitian dan Pengembangan Kesehatan, 2010.

4. Dinas Kesehatan Provinsi Riau. Profil Kesehatan Provinsi Riau. Pekanbaru: Dinas Kesehatan Provinsi Riau, 2010.

5. Kementerian Kesehatan RI. Rencana aksi pembinaan gizi masyarakat (RAPGM) tahun 2010-2014. Jakarta: Dirjen Bina Gizi dan KIA, 2011.

6. Muchina, E.N. and Waithaka P.M. Relationship Between Breastfeeding Practices and Nutritional Status of Children Aged 0-24 Months in Nairobi, Kenya. Afjand, 2010; 10 (4) : 2358-76.

7. Ergin F, Okyay P, Atasoylu G, and Beser $E$. Nutritional status and risk factors of chronic malnutrition in children under five years of age in Aydin, a western city of Turkey. Turk J Pediatr, 2007; 49: 283-289.

8. Riyadi $H$, Martianto D, Hastuti D, Damayanthi $\mathrm{E}$, and Murtilaksono $\mathrm{K}$. Faktor-faktor yang Mempengaruhi Status Gizi Anak Balita di Kabupaten Timor Tengah Utara, Provinsi Nusa Tenggara Timur. Jurnal Gizi dan Pangan, 2011; 6 (1) :66-73.

9. Kumar D, Goel NK, Mittal PC, and Misra $P$. Influence of Infant-Feeding Practices on Nutritional Status of Under Five Children. Indian J Pediatr, 2006; 73 (5) : 417-21.

10. Lemeshow S, Hosmer DW, Klar J, Lwanga S. Besar sampel dalam penelitian kesehatan. Alih bahasa Pramono, D. dan Kusnanto, H. Yogyakarta: Gadjah Mada University Press, 1997.
11. Dinas Kesehatan Kota Pekanbaru. Laporan PSG tahun 2013. Pekanbaru: Dinas Kesehatan Kota Pekanbaru, 2013.

12. World Health Organization. Levels and Trends in Child malnutrition. Geneva: WHO, 2012.

13. World Health Organization. Nutrition Landscape Information System (NLIS). Country Profile Indicators. Geneva: WHO, 2010.

14. Souganidis E. The relevance of micronutrients to the prevention of stunting. Sight and life, 2012; 26 (2): 10 18.

15. UNICEF. Causes and consequences of stunting: An opportunity to improve health and economic development. Vietnam: UNICEF, 2012.

16. Sugiharto $M$ and Widjiartini. Analisis pencapaian target program promosi kesehatan menurut jenis puskesmas di Kabupaten Tulungagung. Buletin Penelitian Sistem Kesehatan, 2012;15 (4): 369-380.

17. World Health Organization. Promoting proper feeding for infants and young children. Geneva: WHO, 2013.

18. Meshram, Laxmaiah $A$, Venkaiah $K$, and Brahmam GNV. Impact of feeding and breastfeeding practices on the nutritional status of infants in a district of Andhra Pradesh, India. Natl Med J India, 2012;25 (4):201-6.

19. Meiliany, Rasyad AS, Hilmanto D. Faktor risiko status gizi kurang pada bayi usia 6 bulan. J Indon Med Assoc. 2011;61(11): 442-446.

20. Teshome B, Kogi-Makau W, Getahun Z, and Taye G. Magnitude and determinants of stunting in children under five years of age in food surplus region of Ethiopia: the case of West Gojam Zone. Ethiop J Health Dev. 2009; 23(2):98-106.

21. Magalhaes TCA, Vieira SA, Priore SE, Ribeiro $A Q$, Lamounier JA, Franceschini SCC, et al. Exclusive breastfeeding and other foods in the first six months of life: effects on nutritional status and body composition of Brazilian children. The Scientific Worls Journal, 2012; 21(Oct): 468581- 468589

22. Rachmadewi $A$ and Khomsan $A$. Pengetahuan, sikap, dan praktek ASI 
eksklusif serta status gizi bayi usia 4-12 bulan di pedesaan dan perkotaan. Jurnal Gizi dan Pangan, 2009; 4(2): 83-90.

23. Luthra M, Kishor S, Jain K. Epidemiology of undernutrition in children between 0-5 years from rural areas of Dehradun. Indian Journal of Community Health, 2010; 21(2) :18-21.

24. Paudel R, Pradhan B, Wagle RR, Pahari $D$, Onta SR. Risk factors for stunting among children: A community based case control study in Nepal. Kathmandu Univ Med J, 2012; 39(3): 18-24.

25. Macharia CW, Kogi-Macau W, NM Muroki. A Comparative Study on The Nutritional Status of Children (6-59 months) In A World Vision Project Area and $A$ Non Project Area In Kathonzweni Division, Makueni District, Kenya. Afjand, 2005; 5 (1): 1-13.
26. Soetardjo, S. Gizi anak. In: Almatsier, S (ed). Gizi Seimbang dalam Daur Kehidupan. Jakarta: Gramedia, 2011.

27. Appoh LY and Krekling S. Maternal nutritional knowledge and child nutritional status in the Volta Region of Ghana. Maternal and Child Nutrition, 2005; 1(2): 100-110.

28. Soenardi, T. Gizi seimbang untuk bayi dan balita. In: Soekirman, Susana, H., Giarno, M.H., \& Lestari, Y. (eds). Hidup Sehat: Gizi Seimbang dalam Siklus Kehidupan Manusia. Jakarta: Primamedia Pustaka, 2006. 
